\title{
Methane and nitrous oxide sources and emissions in a subtropical freshwater reservoir, South East Queensland, Australia
}

\author{
K. Sturm ${ }^{1}$, Z. Yuan ${ }^{1}$, B. Gibbes ${ }^{2}$, U. Werner ${ }^{1}$, and A. Grinham ${ }^{1,2}$ \\ ${ }^{1}$ Advanced Water Management Centre (AWMC), The University of Queensland, Level 4, Gehrmann Building, Brisbane, \\ Queensland 4072, Australia \\ ${ }^{2}$ School of Civil Engineering, The University of Queensland, Level 5, Advanced Engineering Building, Brisbane, \\ Queensland 4072, Australia
}

Correspondence to: A. Grinham (a.grinham@uq.edu.au)

Received: 31 October 2013 - Published in Biogeosciences Discuss.: 11 December 2013

Revised: 7 August 2014 - Accepted: 30 August 2014 - Published: 30 September 2014

\begin{abstract}
Reservoirs have been identified as an important source of non-carbon dioxide $\left(\mathrm{CO}_{2}\right)$ greenhouse gases with wide ranging fluxes for reported methane $\left(\mathrm{CH}_{4}\right)$; however, fluxes for nitrous oxide $\left(\mathrm{N}_{2} \mathrm{O}\right)$ are rarely quantified. This study investigates $\mathrm{CH}_{4}$ and $\mathrm{N}_{2} \mathrm{O}$ sources and emissions in a subtropical freshwater Gold Creek Reservoir, Australia, using a combination of water-air and sediment-water flux measurements and water column and pore water analyses. The reservoir was clearly a source of these gases as surface waters were supersaturated with $\mathrm{CH}_{4}$ and $\mathrm{N}_{2} \mathrm{O}$. Atmospheric $\mathrm{CH}_{4}$ fluxes were dominated by ebullition (60 to $99 \%$ ) relative to diffusive fluxes and ranged from $4.14 \times 10^{2}$ to $3.06 \times 10^{5} \mu_{\mathrm{mol} \mathrm{CH}} \mathrm{m}^{-2}$ day $^{-1}$ across the sampling sites. Dissolved $\mathrm{CH}_{4}$ concentrations were highest in the anoxic water column and sediment pore waters (approximately $5000000 \%$ supersaturated). $\mathrm{CH}_{4}$ production rates of up to $3616 \pm 395 \mu \mathrm{mol} \mathrm{CH} 4 \mathrm{~m}^{-2}$ day $^{-1}$ were found during sediment incubations in anoxic conditions. These findings are in contrast to $\mathrm{N}_{2} \mathrm{O}$ where no production was detected during sediment incubations and the highest dissolved $\mathrm{N}_{2} \mathrm{O}$ concentrations were found in the oxic water column which was 110 to $220 \%$ supersaturated with $\mathrm{N}_{2} \mathrm{O} . \mathrm{N}_{2} \mathrm{O}$ fluxes to the atmosphere were primarily through the diffusive pathway, mainly driven by diffusive fluxes from the water column and by a minor contribution from sediment diffusion and ebullition. Results suggest that future studies of subtropical reservoirs should monitor $\mathrm{CH}_{4}$ fluxes with an appropriate spatial resolution to ensure capture of ebullition zones, whereas assessment of $\mathrm{N}_{2} \mathrm{O}$ fluxes should focus on the diffusive pathway.
\end{abstract}

\section{Introduction}

Methane $\left(\mathrm{CH}_{4}\right)$ and nitrous oxide $\left(\mathrm{N}_{2} \mathrm{O}\right)$ are powerful greenhouse gases (GHGs) and are of emerging environmental concern. Their global warming potentials (GWPs) are 25 and 310 times that of carbon dioxide $\left(\mathrm{CO}_{2}\right)$, respectively, when calculated on a 100-year time horizon (IPCC, 2007). Man-made reservoirs, which include those for hydropower, agriculture or drinking water purposes, are now considered significant contributors of these GHGs, particularly $\mathrm{CH}_{4}$ (Barros et al., 2011; Bastviken et al., 2011; St. Louis et al., 2000). The recognition of reservoirs as anthropogenic sources of GHGs has thus increased global interest in the measurement, monitoring and modelling of these emissions. The result is a discontinuous database of a large range of primarily $\mathrm{CH}_{4}$ fluxes, of which studies in potentially important areas, such as the tropics and subtropics as well as whole continents like Australia, remain scarce (Mendonça et al., 2012; Ortiz-Llorente and Alvarez-Cobelas, 2012; St. Louis et al., 2000). Fewer studies conducted worldwide have analysed the contribution of $\mathrm{N}_{2} \mathrm{O}$ to $\mathrm{GHG}$ emissions from reservoirs (Guerin et al., 2008; Mengis et al., 1997; Tremblay et al., 2005) despite $\mathrm{N}_{2} \mathrm{O}$ having a higher GWP than $\mathrm{CH}_{4}$. There are currently only two studies (Bastien and Demarty, 2013; Grinham et al., 2011) reporting $\mathrm{CH}_{4}$ emissions and none for $\mathrm{N}_{2} \mathrm{O}$ from reservoirs in Australia - a country with over 2300 reservoirs covering a surface area in excess of $5700 \mathrm{~km}^{2}$ at full supply (Geoscience Australia, 2004).

Freshwater reservoirs in Australia cover a large surface area and are essential for drinking water supply and irrigation purposes. These reservoirs are typically closed systems 
without continuous release through a dam but may have periodic release for environmental flows and drinking water supplies. These reservoirs enable storage and greater certainty of supply compared to river and groundwater sources in Australia. In reservoirs without continuous water release, the primary $\mathrm{CH}_{4}$ emission pathways to the atmosphere are ebullition from sediments, diffusion over the water-air interface and plant-mediated transport from littoral zones (Bastviken et al., 2004). Ebullition has been shown to be the dominant $\mathrm{CH}_{4}$ emission pathway in many tropical systems (DelSontro et al., 2011; Devol et al., 1988; Grinham et al., 2011; Joyce and Jewell, 2003; Keller and Stallard, 1994; Soumis et al., 2005). Factors controlling $\mathrm{CH}_{4}$ ebullition in lake systems are relatively well known (Bastviken et al., 2004; Joyce and Jewell, 2003; Ortiz-Llorente and AlvarezCobelas, 2012); however, the dynamics and the spatial distribution of ebullition are not well understood (DelSontro et al., 2011; Ostrovsky et al., 2008; Ramos et al., 2006). $\mathrm{CH}_{4}$ is typically produced by the process of methanogenesis under anoxic conditions (Canfield et al., 2005) as found in the sediment and hypolimnetic zones of a reservoir. However, zones within a reservoir may contain large gradients in dissolved oxygen (DO) availability (such as at the metalimnion under stratified conditions or upper layers of shallow sediments) and promote oxidation of dissolved $\mathrm{CH}_{4}$ via methanotrophic bacteria (Guerin and Abril, 2007), which can greatly reduce diffusive emissions from the water surface.

$\mathrm{N}_{2} \mathrm{O}$ production or consumption is also associated with these zones where large DO gradients occur. Under oxic conditions, as found in the epilimnion or metalimnion, $\mathrm{N}_{2} \mathrm{O}$ is primarily produced as a byproduct of nitrification. At oxicanoxic boundaries, $\mathrm{N}_{2} \mathrm{O}$ is produced as an intermediate of denitrification (Mengis et al., 1997; Ward, 1996) or can be reduced to nitrogen gas during denitrification (Lipschultz et al., 1990; Mengis et al., 1997). In stratified reservoirs, the oxic-anoxic boundaries are found in the water column. In well-mixed systems or at shallow sites, DO can reach the sediment surface, and thus $\mathrm{N}_{2} \mathrm{O}$ can be produced in the water column as well as in the upper layers of sediment.

The low-latitude reservoirs of Australia provide ideal conditions for GHG production, consumption and emissions. The generally higher temperatures experienced in tropical regions drive thermal stratification and a rapid deoxygenation of bottom waters (Barros et al., 2011; Tundisi and Tundisi, 2012). Irregular and heavy precipitation events can lead to the input of high organic carbon loads into the water body (Tundisi et al., 1993). The organic carbon loads together with elevated temperatures and deoxygenated bottom waters of these reservoirs will provide conditions that enhance $\mathrm{CH}_{4}$ production and emissions (Demarty and Bastien, 2011; Fearnside, 1995; Galy-Lacaux et al., 1999). The steep oxygen gradients and high ammonium turnover found in subtropical reservoirs will likely favour $\mathrm{N}_{2} \mathrm{O}$ production (Guerin et al., 2008).
There is recent emphasis to further study $\mathrm{CH}_{4}$ emissions from freshwater reservoirs (Barros et al., 2011; Bastviken et al., 2011; Demarty and Bastien, 2011; St. Louis et al., 2000), and this has stimulated an increase of $\mathrm{CH}_{4}$ monitoring. However, studies of $\mathrm{N}_{2} \mathrm{O}$ emissions are lacking (Mengis et al., 1997; Seitzinger and Kroeze, 1998) despite $\mathrm{N}_{2} \mathrm{O}$ being a more potent GHG than $\mathrm{CH}_{4}$. Although GHG studies from reservoirs have recently increased, they remain limited, particularly in subtropical/tropical regions of the Southern Hemisphere (Mendonça et al., 2012; Ortiz-Llorente and Alvarez-Cobelas, 2012; St. Louis et al., 2000). Consequently, through this shortfall a large gap in the understanding of global $\mathrm{CH}_{4}$ and $\mathrm{N}_{2} \mathrm{O}$ emissions persists.

In our study we investigated $\mathrm{CH}_{4}$ and $\mathrm{N}_{2} \mathrm{O}$ emissions, production and consumption processes in the Gold Creek Reservoir in South East Queensland, Australia. The study consisted of two main parts. First, a detailed field investigation of the $\mathrm{CH}_{4}$ and $\mathrm{N}_{2} \mathrm{O}$ emission rates at two sites (one deep and one shallow) by measuring total water-air fluxes as well as water column and pore water concentrations. The detailed study also included sediment-water flux incubations of the shallow site which were conducted in the laboratory to gain further insight of the $\mathrm{CH}_{4}$ and $\mathrm{N}_{2} \mathrm{O}$ production or consumption processes. Secondly, a spatial emission field study focused on total flux (ebullitive and diffusive) measurements and estimated diffusive fluxes was performed to assess the $\mathrm{CH}_{4}$ and $\mathrm{N}_{2} \mathrm{O}$ emissions from shallow and deep sites of the reservoir. This study examined and validated the spatial and temporal representativeness of the $\mathrm{CH}_{4}$ and $\mathrm{N}_{2} \mathrm{O}$ emission data from the two sites of the detailed investigation.

\section{Materials and methods}

\subsection{Site description}

Gold Creek Reservoir $\left(27^{\circ} 45^{\prime} 97^{\prime \prime} \mathrm{S}, 152^{\circ} 87^{\prime} 86^{\prime \prime} \mathrm{E}\right)$ is located in subtropical South East Queensland, $14 \mathrm{~km}$ west of the city of Brisbane, Australia. Completed in 1885, the reservoir is one of the oldest reservoirs in Australia and was built for the supply of drinking water to Brisbane (although currently not used for this purpose). Gold Creek Reservoir has a surface area of 19 ha and is near the median size for Australian reservoirs. The reservoir has a capacity of $820000 \mathrm{~m}^{3}$ and maximum water depth of $11.75 \mathrm{~m}$ at full supply. Approximately $65 \%$ of the total storage capacity is within the upper $2 \mathrm{~m}$ of the reservoir (Supplement Table S1). The reservoir's pristine catchment area is $10.5 \mathrm{~km}^{2}$ and consists of $98 \%$ open eucalyptus forest (Queensland Department of Science Information Technology Innovation and the Arts, 2012). These steep, forested catchments export high amounts of organic matter in the form of senescent leaves and woody material during intensive precipitation events (Tundisi et al., 1993). This material is generally deposited in the inflow points of 
reservoirs where ebullition is frequently observed (Grinham et al., 2011).

In contrast to many temperate systems and reservoirs used for hydropower, Gold Creek Reservoir experiences water level increases mainly by intensive, irregular precipitation events and subsequent inflows especially during the summer months (e.g. $444 \mathrm{~mm}$ in 4 days, January 2013; Bureau of Meteorology, 2013). Water level decreases are caused by water evaporation due to the warm temperatures (annual mean temperature $26.4^{\circ} \mathrm{C}$; Bureau of Meteorology, 2013). As Gold Creek Reservoir has no regular release of water via dam outlets, the turbulent exchange of $\mathrm{CH}_{4}$ and $\mathrm{N}_{2} \mathrm{O}$ to the atmosphere is restricted to when the reservoir's capacity is exceeded and water is released over a spillway. The reservoir is steep-sided with limited colonisation of rooted macrophytes, limiting the importance of plant-mediated emission pathways. This means that the main emission pathways for Gold Creek Reservoir are ebullition from sediments and diffusion via the water-air interface.

Located in a subtropical region, Gold Creek Reservoir has relatively high water temperatures compared with many temperate systems. Monthly monitoring of water column profiles using a multi-parameter sonde (YSI 6600, YSI Inc., Yellow Springs, OH, USA) showed seasonal ranges of surface water temperature from $14{ }^{\circ} \mathrm{C}$ in winter (June to August) to $30^{\circ} \mathrm{C}$ in summer (December to February) and bottom water temperatures ranging between 14 to $16^{\circ} \mathrm{C}$ in all seasons. The water column was oxygenated in the upper $2 \mathrm{~m}$ during all seasons and stratified for 10 months of the year. Water column profiles of chlorophyll $a$ were taken with a chlorophyll fluorometer (Seapoint Sensors Inc., Exeter, NH, USA). Sampling and experiments for this study were conducted in March 2012 and February 2014. During these periods, stratified conditions predominated, the reservoir was consistently filled to $90-100 \%$ and experienced no overspill.

In the first part of our study, the detailed investigation was conducted at a shallow site (s4) and a deep site (d7) (Fig. 1; Supplement Table S2). $\mathrm{CH}_{4}$ and $\mathrm{N}_{2} \mathrm{O}$ total water-air fluxes and water column concentrations from both sites were measured as well as pore water concentrations from the shallow site s4. Additionally, laboratory incubations of sediments from sampling site $\mathrm{s} 4$ were conducted to determine $\mathrm{CH}_{4}$ and $\mathrm{N}_{2} \mathrm{O}$ production as this site was located at the oxycline zone.

The second part of this study investigated the spatial variability of emissions and focused on total flux measurements and diffusive flux estimates at several shallow sites (s1-s4) and deep sites (d5-d8) (Fig. 1; Supplement Table S2). The data obtained in this study were also used to validate the representativeness of water-air emission estimates from sites $\mathrm{s} 4$ and $\mathrm{d} 7$ of the detailed study. The average depth of the shallow sampling sites, located in the reservoir's sidearms, was $1.7 \pm 0.5 \mathrm{~m}$. The deep sampling sites, with an average depth of $7.9 \pm 2.7 \mathrm{~m}$, were generally located in the middle of the reservoir body.

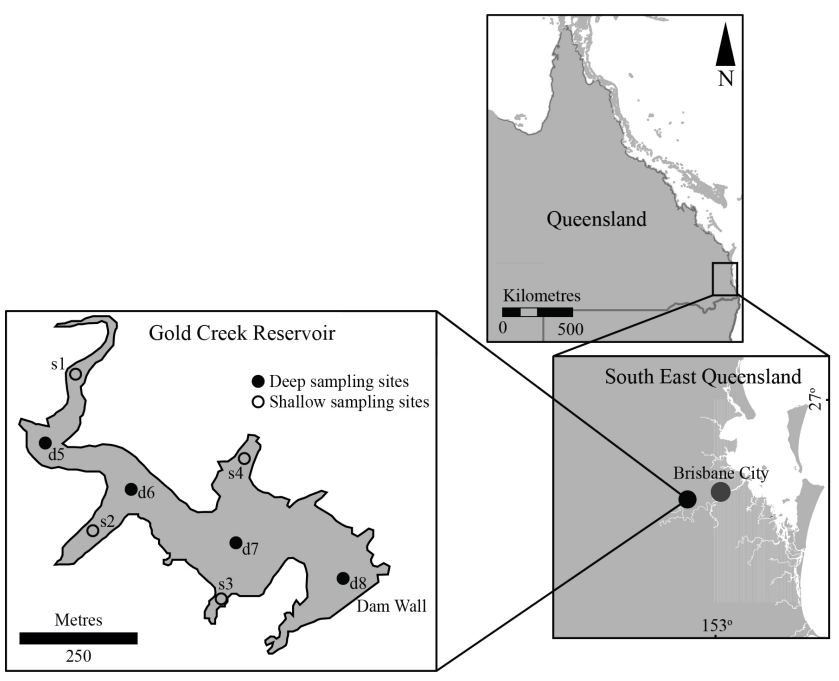

Figure 1. The location of the sampling sites at the Gold Creek Reservoir, South East Queensland, Australia. Sampling sites are numbered from the shallowest to deepest sites. Water depths were for the sites s1: $1.1 \mathrm{~m}, \mathrm{~s} 2: 1.7 \mathrm{~m}, \mathrm{~s} 3: 1.9 \mathrm{~m}, \mathrm{~s} 4: 2.1 \mathrm{~m}, \mathrm{~d} 5: 4.4 \mathrm{~m}, \mathrm{~d} 6$ : $7.5 \mathrm{~m}, \mathrm{~d} 7: 9.7 \mathrm{~m}, \mathrm{~d} 8: 10.2 \mathrm{~m}$ during the spatial emission study. The detailed study was undertaken at sites s4 and $\mathrm{d} 7$.

\subsection{Field measurements}

\subsubsection{Water-air flux measurements}

Total $\mathrm{CH}_{4}$ and $\mathrm{N}_{2} \mathrm{O}$ emission fluxes (both ebullitive and diffusive fluxes) at the water-air interface were determined using anchored surface floating chambers. Gas accumulation of ebullitive and diffusive water-air fluxes in the chambers over time was used for rate calculations. Diffusive water-air fluxes were estimated using the thin boundary layer (TBL) model (Cole et al., 2010). Ebullitive emissions were calculated by the difference between total (floating chamber) and diffusive (TBL model) fluxes.

The surface floating chambers used are described in Grinham et al. (2011) and consisted of a floating platform with six small cylindrical PVC chamber units as replicates each with a volume of $0.00048 \mathrm{~m}^{3}$, and surface area of $0.00583 \mathrm{~m}^{2}$. The chambers were stabilised in the water column by anchoring at two points to the reservoir's floor using an anchor system that was attached to each chamber at two opposite sides. The ropes used for this were connected to a sub-surface floating buoy which was again connected by ropes to an anchor on the reservoir ground. Sampling-induced disturbances to the water column and sampling-induced ebullition from the sediments were minimised by a careful approach and by maintaining boat speeds below $2.5 \mathrm{kn}$.

Headspace gas samples were taken from the floating chambers to determine emission rates after known deployment periods. During the detailed study at sites s4 and d7, gas samples were taken every $24 \mathrm{~h}$ from each of the six replicate units per floating chamber. After sampling, the surface 
floating chambers were lifted out of the water and flushed with air. This sampling procedure was repeated 5 times over 5 consecutive days. During the spatial emission study, surface floating chambers with three replicate units per chamber were deployed at sites $\mathrm{s} 1-\mathrm{s} 4$ and at sites $\mathrm{d} 5-\mathrm{d} 8$. In this study, the chamber deployment time was $1 \mathrm{~h}$. After taking gas samples from all chamber units, the chambers were also lifted out of the water and flushed with air. This sampling procedure was repeated 3 times at each site. Gas from the chambers was sampled using a $60 \mathrm{~mL}$ syringe with a $0.64 \mathrm{~mm}$ needle (Livingstone International Pty. Ltd., Rosebery, NSW, Australia) and transferred into $12 \mathrm{~mL}$ pre-evacuated borosilicate vials (Exetainer, Labco Ltd., Lampeter, UK).

Diffusive water-air fluxes were estimated using the equation:

$F=k \times \Delta C=k \times\left(C_{\mathrm{w}}-C_{\mathrm{eq}}\right)$,

where $F$ is the flux $\left(\mu \mathrm{mol} \mathrm{m}{ }^{-2} \mathrm{day}^{-1}\right), k$ is the gas transfer coefficient $\left(\mathrm{m} \mathrm{day}^{-1}\right)$ and $\Delta C$ is the difference between the gas concentration in the surface water $\left(C_{\mathrm{w}}\right)$ and the gas concentration in the surface water that is in equilibrium with the air $\left(C_{\text {eq }}\right)$ (Cole et al., 2010).

The gas transfer coefficient $k$ was estimated using the model, Eq. (2), developed by Wanninkhof (1992):

$k=a \times U_{10}^{2} \times(S c / 600)^{-x}$,

where $a$ is 0.31 for short-term winds or 0.39 for steady winds, $U_{10}$ is the frictionless wind speed $\left(\mathrm{m} \mathrm{s}^{-1}\right)$ normalised at $10 \mathrm{~m}, \mathrm{Sc}$ is the Schmidt number for $\mathrm{CH}_{4}$ and $\mathrm{N}_{2} \mathrm{O}$ and $x$ is a constant depending on the wind speed $(x=0.66$ for wind speed $<3 \mathrm{~m} \mathrm{~s}^{-1}$ or $x=0.5$ for wind speed $\left.>3 \mathrm{~m} \mathrm{~s}^{-1}\right)$. The Schmidt number $S c$ was calculated (Wanninkhof, 1992) using Eqs. (3) and (4) for $\mathrm{CH}_{4}$ and $\mathrm{N}_{2} \mathrm{O}$, respectively:

$$
\begin{aligned}
S c\left(\mathrm{CH}_{4}\right) & =1897.8-114.28 \times t+3.2902 \times t^{2} \\
& -0.039061 \times t^{3}, \\
S c\left(\mathrm{~N}_{2} \mathrm{O}\right) & =2055.6-137.11 \times t+4.3173 \times t^{2} \\
& -0.054350 \times t^{3},
\end{aligned}
$$

where $t$ is the temperature in Celsius. The frictionless wind speed $U_{10}$ was normalised to a height of $10 \mathrm{~m}$ according to Crusius and Wanninkhof (2003):

$U_{10}=1.22 \times U_{1}$,

where $U_{1}$ is the wind speed at $1 \mathrm{~m}$ height $\left(\mathrm{m} \mathrm{s}^{-1}\right)$.

$C_{\mathrm{w}}$ was measured from a water sample (explained in the next section), whereas $C_{\text {eq }}$ was calculated with the solubility approaches of Yamamoto et al. (1976) for $\mathrm{CH}_{4}$ and Weiss and Price (1980) for $\mathrm{N}_{2} \mathrm{O}$ and measured atmospheric concentrations before starting the chamber deployment times. A weather transmitter (WXT520, Vaisala, Vantaa, Finland) was installed during all sampling times at site $\mathrm{d} 7$ and the average wind speeds were logged every minute (Supplement Figs. S1 and S2a). The wind speeds used for calculations were averaged over $24 \mathrm{~h}$ for each of the 5 consecutive measurement days for the detailed study and were averaged over the $1 \mathrm{~h}$ sampling intervals for the spatial emission study.

\subsubsection{Water column sampling}

Water column samples were taken at sites $\mathrm{s} 4$ and $\mathrm{d} 7$ to determine the concentrations of $\mathrm{CH}_{4}, \mathrm{~N}_{2} \mathrm{O}$ and for the nutrient levels of ammonium $\left(\mathrm{NH}_{4}^{+}\right)$, nitrate $\left(\mathrm{NO}_{3}^{-}\right)$and nitrite $\left(\mathrm{NO}_{2}^{-}\right)$. Samples were taken from the epilimnion $(20 \mathrm{~cm}$ below the water surface) and at the metalimnion depth (2 m) with a 4.2 L Niskin water sampler (Wildco, Wildlife Supply Company, Yulee, FL, USA) daily over the 5 consecutive days. At site d7, samples were also taken from the hypolimnion $(8 \mathrm{~m}$ depth). All water samples were pressurefiltered through $25 \mathrm{~mm}$ diameter, $0.22 \mu \mathrm{m}$ pore-size filters (Merck Millipore, Billerica, MA, USA). Water samples for $\mathrm{CH}_{4}$ and $\mathrm{N}_{2} \mathrm{O}$ analyses were injected into pre-evacuated borosilicate vials using a $12 \mathrm{~mL}$ syringe with a $0.64 \mathrm{~mm}$ needle, then equilibrated in an inflatable glove bag filled with ultra-high purity nitrogen gas (BOC, Brisbane, Australia) to atmospheric pressure and then stored at $4{ }^{\circ} \mathrm{C}$ until analysis. Water samples used for nutrient analyses were stored in sterile $10 \mathrm{~mL}$ vials (Sarstedt AG \& Co., Nümbrecht, Germany) and frozen until analysis was carried out.

\subsubsection{Pore water sampling}

To investigate sediments as potential sources of $\mathrm{CH}_{4}$ and $\mathrm{N}_{2} \mathrm{O}$, pore waters were extracted from sediment samples and analysed for $\mathrm{CH}_{4}$ and $\mathrm{N}_{2} \mathrm{O}$ concentrations at the shallow site s4. For this, six undisturbed sediment cores were taken with a gravity corer (Envco Environmental Equipment Suppliers, Australia), fitted with acrylic liners $(69 \mathrm{~mm}$ inner diameter, $500 \mathrm{~mm}$ long) and sealed with PVC caps. The gravity corer used had a $2 \mathrm{~m}$ pole which limited the collection depth to a shallow site (i.e. site s4). However, Gold Creek Reservoir is generally shallow, with the main storage capacity being within the upper $2 \mathrm{~m}$ of the storage (Supplement Table S1). Therefore the oxycline of the reservoir is around the $2 \mathrm{~m}$ mark (Supplement Fig. S3a) and most sediments of the reservoir are exposed to oxygen. Thus, sediments of the chosen shallow site may be, at least in terms of oxygen exposure, representative for most of the reservoir's sediments.

Collected sediments in the cores had a height of $11.54 \pm 2.34 \mathrm{~cm}$. For the pore water analysis, sediment cores were pushed up to the top of the acrylic liners and $2 \mathrm{~cm}$ sediment layers were transferred into $50 \mathrm{~mL}$ test tubes (Falcon tubes, BD Biosciences, San Jose, CA, USA). Care was taken to ensure no headspace was formed. However, method drawbacks due to possible gas leakage from the vials would lead to an underestimation of pore water concentrations if the investigated gases are supersaturated. Upon arrival in the 
laboratory, sediments in the test tubes were centrifuged (Eppendorf AG, Hamburg, Germany) for $20 \mathrm{~min}$ at $1500 \mathrm{~g}$, without pressure or temperature changes. The pore water (supernatant) was removed and stored at $4{ }^{\circ} \mathrm{C}$ until analysis for $\mathrm{CH}_{4}, \mathrm{~N}_{2} \mathrm{O}, \mathrm{NH}_{4}^{+}, \mathrm{NO}_{3}^{-}$and $\mathrm{NO}_{2}^{-}$. Sample handling as well as sample equilibration of the gases followed the same procedure as described previously for the water column samples.

\subsection{Sediment incubation study}

Sediment incubations were conducted in the laboratory to determine $\mathrm{CH}_{4}$ and $\mathrm{N}_{2} \mathrm{O}$ sediment-water fluxes from the shallow site samples (s4). For this, a second set of six undisturbed sediment core replicate samples were collected at site $\mathrm{s} 4$ with a gravity corer as described previously. The collected sediments had a height of $9.79 \pm 1.12 \mathrm{~cm}$ with an overlying water column of $40.21 \pm 1.12 \mathrm{~cm}$. The covered sediment cores were transferred to the laboratory within $4 \mathrm{~h}$, placed into incubators and the top PVC caps were removed. The incubators were filled with surface water from the respective site. The water was adjusted to the in situ temperature $\left(24^{\circ} \mathrm{C}\right)$ using water chillers. The open sediment cores were left to settle overnight while the water column above each sediment core was gently stirred using a magnetic stirring bar suspended in the water column and propelled by additional stirrer bars rotating at $18 \mathrm{rpm}$ adjacent to the incubators. Results from in situ deployments of underwater light loggers (Odyssey photosynthetic active radiation recorders, Dataflow Systems Pty. Ltd., Christchurch, New Zealand) indicated strong light attenuation at the reservoir, with the photic zone being less than 1 to $0.5 \mathrm{~m}$ (Supplement Fig. S4). Consequently, for these sediment studies the incubators were covered with aluminum foil on the sides and light-blocking cloth at the top to mimic the reservoir's sediment conditions below the photic zone.

The sediment core liners were capped $15 \mathrm{~h}$ after sampling using plexiglas lids with O-rings taking care to exclude air bubbles. The lids contained three ports for sampling, refilling and for a dissolved oxygen probe (tip sealed against sampling port). One-way valves were attached to the tubing (Masterflex Tygon, John Morris Scientific Pty. Ltd., Chatswood, NSW, Australia) of the sampling and refilling ports, and a rubber stopper was used for the oxygen probe port if not used. Sampling and refilling with site water were carried out with $20 \mathrm{~mL}$ syringes. Dissolved oxygen and temperature of the water column above the sediment cores were monitored using an optical DO probe (PreSens, Precision Sensing $\mathrm{GmbH}$, Regensburg, Germany) before the core liners were capped and every $24 \mathrm{~h}$ subsequently until the experiment finished. Cores were regularly inspected for signs of ebullition (bubble formation under the cap) throughout the incubation times. Samples from the overlying water of the sediment cores were taken for analysis of $\mathrm{CH}_{4}, \mathrm{~N}_{2} \mathrm{O}$ and the nutrients $\mathrm{NH}_{4}^{+}, \mathrm{NO}_{3}^{-}$and $\mathrm{NO}_{2}^{-}$before the cores were capped and after 72,120 and $288 \mathrm{~h}$ incubation. Daily fluxes were determined for $\mathrm{CH}_{4}, \mathrm{NH}_{4}^{+}, \mathrm{NO}_{3}^{-}$and $\mathrm{NO}_{2}^{-}$over $288 \mathrm{~h}$ and for $\mathrm{DO}$ over
$48 \mathrm{~h}$. These were calculated from the rates of change in concentration and by taking the core volume and sediment surface area into account. $\mathrm{CH}_{4}, \mathrm{~N}_{2} \mathrm{O}$ and nutrient sample handling as well as sample equilibration of the gases followed the same procedure as described previously for the water column samples.

\subsection{Analyses}

Both gaseous and liquid samples were analysed for $\mathrm{CH}_{4}$ and $\mathrm{N}_{2} \mathrm{O}$ concentrations using an Agilent GC7890A gas chromatograph (Agilent Technologies, Santa Clara, CA, USA). A flame ionisation detector and a micro-electron capture detector were used for the analysis of $\mathrm{CH}_{4}$ and $\mathrm{N}_{2} \mathrm{O}$, respectively. The gas chromatograph was calibrated using standards with a range of 1.8 to $82000 \mathrm{ppm}$ for $\mathrm{CH}_{4}$ and 0.5 to $50.53 \mathrm{ppm}$ for $\mathrm{N}_{2} \mathrm{O}$ which were prepared from certified gas standards (BOC gases, Brisbane, Australia). A Lachat QuickChem 8000 Flow Injection Analyzer (Lachat Instrument, Milwaukee, WI, USA) was used for the analysis of $\mathrm{NH}_{4}^{+}, \mathrm{NO}_{3}^{-}$and $\mathrm{NO}_{2}^{-}$concentrations.

Statistical analyses were performed with the program Statistica version 12 (StatSoft Inc., Tulsa, OK, USA), using one-way analysis of variances (ANOVAs). In order to evaluate differences amongst sampling sites, one-way ANOVAs were performed with sampling sites $\mathrm{s} 4$ or $\mathrm{d} 7$, sampling days 1-5 or the sampling depths (epilimnion, metalimnion, hypolimnion, pore water) as the categorical predictor and $\mathrm{CH}_{4}$, $\mathrm{N}_{2} \mathrm{O}$ or nutrients $\left(\mathrm{NH}_{4}^{+}, \mathrm{NO}_{3}^{-}, \mathrm{NO}_{2}^{-}\right)$as the continuous variables. Data were log transformed where necessary to ensure normality of distribution and homogeneity of variance (Levene's test) (Zar, 1984). Post hoc tests were performed using Fisher's LSD (least significant difference) test (Zar, 1984). The non-parametric Kruskal-Wallis (KW) test was used for data which failed to satisfy the assumptions of normality and homogeneity of data after being transformed.

\section{Results}

\subsection{Water-air fluxes}

Sites $\mathrm{s} 4$ (shallow) and d7 (deep) of the detailed study showed significantly different $\left(\mathrm{KW}-\mathrm{H}_{1,60}=41.2, P<0.001\right) \mathrm{CH}_{4}$ emission rates, with the highest rates found at the shallow site s4 (Fig. 2a and c; Table 1). However, there was no significant difference $(P>0.05)$ found in $\mathrm{N}_{2} \mathrm{O}$ emissions between the two sites (Fig. 2b and d; Table 1). Total $\mathrm{CH}_{4}$ and $\mathrm{N}_{2} \mathrm{O}$ fluxes across the 5 consecutive monitoring days were not significantly different $(P>0.05)$ at both sampling sites $s 4$ and d7, apart from $\mathrm{N}_{2} \mathrm{O}$ fluxes at site $\mathrm{s} 4$ between day 4 and day 5 $\left(\mathrm{KW}-\mathrm{H}_{9,60}=47.8, P<0.01\right)$. Results of the detailed study (Fig. 2) showed that diffusive fluxes account for 12 to $40 \%$ of the total $\mathrm{CH}_{4}$ fluxes at site $\mathrm{d} 7$ and less than $3 \%$ at site s4. However, diffusive fluxes estimated by the TBL model explain, in four out of 5 monitoring days, 82 to $100 \%$ of total 

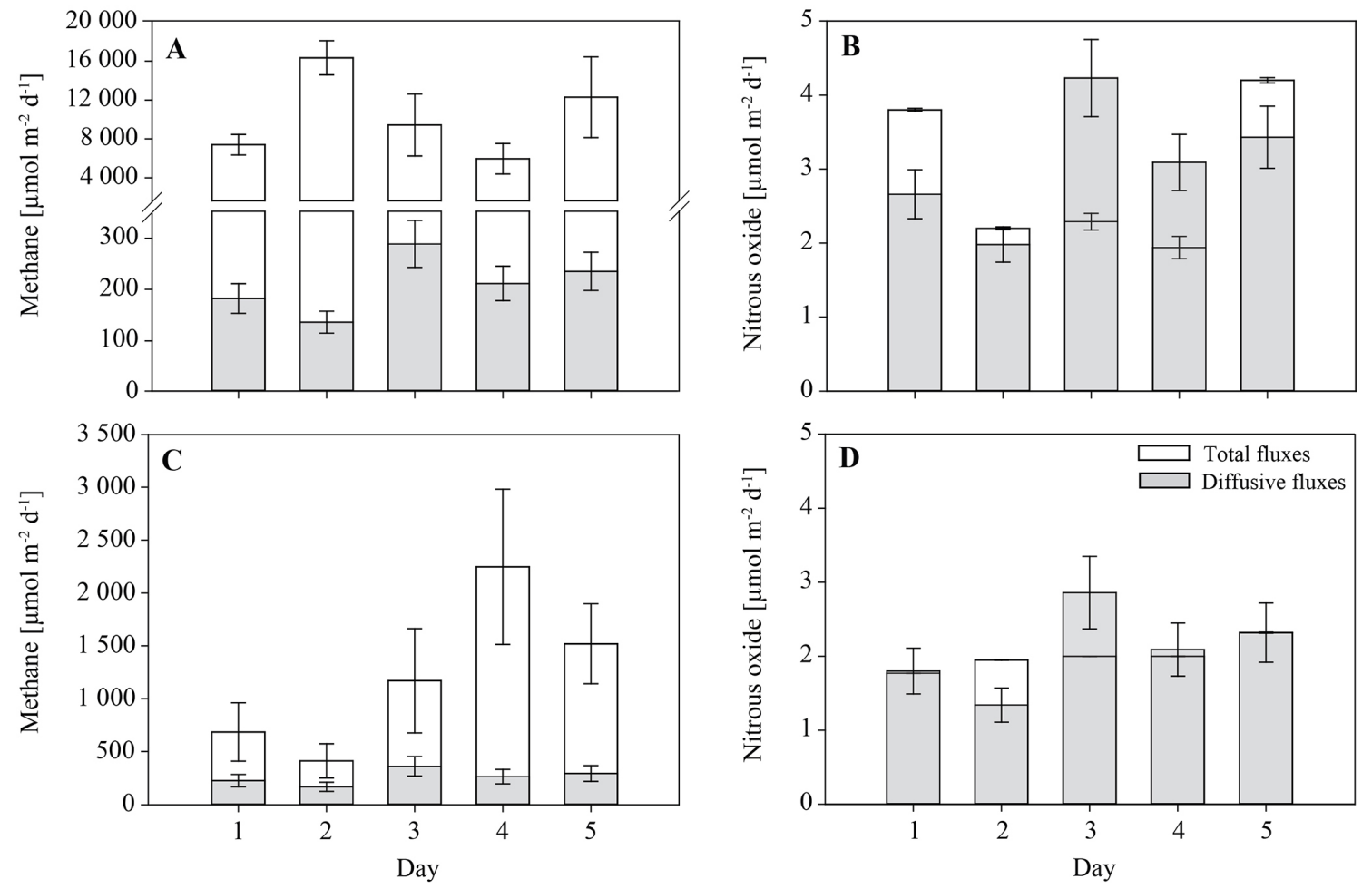

Figure 2. Total and diffusive methane and nitrous oxide fluxes at the shallow sampling site $\mathrm{s} 4$ (a, b) and the deep sampling site d7 (c, d) determined over 5 consecutive days. Total fluxes were determined from measurements using the anchored surface floating chambers, and diffusive fluxes were determined using the thin boundary layer model. Fluxes are given as averages $\pm \mathrm{SE}, n=6$.

Table 1. Total water-air methane and nitrous oxide fluxes at the shallow site s4 and the deep site $\mathrm{d} 7$ of the detailed study. Fluxes are given as the average determined over the 5 consecutive days \pm SE, $n=30$.

\begin{tabular}{|c|c|c|}
\hline Site & $\begin{array}{l}\text { Total } \mathrm{CH}_{4} \text { fluxes } \\
\left(\mu \mathrm{mol} \mathrm{CH} \mathrm{Cm}_{4}^{-2} \mathrm{day}^{-1}\right)\end{array}$ & $\begin{array}{l}\text { Total } \mathrm{N}_{2} \mathrm{O} \text { fluxes } \\
\left(\mu \mathrm{mol} \mathrm{N}_{2} \mathrm{O} \mathrm{m}^{-2} \text { day }^{-1}\right)\end{array}$ \\
\hline s4 & $10423 \pm 1249$ & $2.89 \pm 0.17$ \\
\hline $\mathrm{d} 7$ & $1210 \pm 223$ & $2.01 \pm 0.03$ \\
\hline
\end{tabular}

$\mathrm{N}_{2} \mathrm{O}$ fluxes for both sites. Otherwise, the estimated fluxes exceed the measured fluxes by up to $80 \%$ (Fig. $2 \mathrm{~b}$ and d; discussed in Sect. 4.1).

The spatial emission study confirmed that the Gold Creek Reservoir is a source of both $\mathrm{CH}_{4}$ and $\mathrm{N}_{2} \mathrm{O}$ (Fig. 3; Table 2). However, the results show that $\mathrm{CH}_{4}$ fluxes varied much more widely (6300 to $258535 \mu \mathrm{mol} \mathrm{CH}_{4} \mathrm{~m}^{-2}$ day $^{-1}$ ) than $\mathrm{N}_{2} \mathrm{O}$ fluxes $\left(0.73\right.$ to $\left.1.40 \mu \mathrm{mol} \mathrm{N}{ }_{2} \mathrm{O} \mathrm{m}^{-2} \mathrm{day}^{-1}\right)$. No significant trend was observed for flux differences between shallow and deep sites for either investigated gas, except that $\mathrm{CH}_{4}$ emissions at the shallow site s1 exceeded the emissions of all other sites by $1-2$ orders of magnitude. $\mathrm{CH}_{4}$ emissions at site s1 were significantly different $\left(\mathrm{KW}-\mathrm{H}_{7,72}=41.0, P<0.05\right)$ from all other sampling sites, while significant difference was
Table 2. Total water-air methane and nitrous oxide fluxes at sampling sites s1-s4 and d5-d8 of the spatial emission study. Rates are averaged over three surface floating chamber deployments. Sampling sites are numbered from shallowest to deepest site. Fluxes are given as an average $\pm \mathrm{SE}, n=9$.

\begin{tabular}{|c|c|c|}
\hline Site & $\begin{array}{l}\text { Total } \mathrm{CH}_{4} \text { fluxes } \\
\left(\mu \mathrm{mol} \mathrm{CH} \mathrm{C}_{4} \mathrm{~m}^{-2} \mathrm{day}^{-1}\right)\end{array}$ & $\begin{array}{l}\text { Total } \mathrm{N}_{2} \mathrm{O} \text { fluxes } \\
\left(\mu \mathrm{mol} \mathrm{N} \mathrm{N}_{2} \mathrm{O} \mathrm{m}^{-2} \text { day }^{-1}\right)\end{array}$ \\
\hline s1 & $258535 \pm 37087$ & $0.73 \pm 0.06$ \\
\hline s2 & $21381 \pm 6695$ & $1.24 \pm 0.08$ \\
\hline s3 & $20452 \pm 4164$ & $1.40 \pm 0.06$ \\
\hline s4 & $6726 \pm 2686$ & $1.20 \pm 0.15$ \\
\hline d5 & $28597 \pm 5411$ & $1.10 \pm 0.10$ \\
\hline d6 & $30274 \pm 13023$ & $0.87 \pm 0.05$ \\
\hline d7 & $6300 \pm 932$ & $1.17 \pm 0.08$ \\
\hline $\mathrm{d} 8$ & $15952 \pm 1896$ & $1.22 \pm 0.08$ \\
\hline
\end{tabular}

not detected between emissions from the other sites s2-s4 and $\mathrm{d} 5-\mathrm{d} 8(P>0.05)$. The highest $\mathrm{CH}_{4}$ emissions from the deeper sites were detected at sites $\mathrm{d} 5$ and $\mathrm{d} 6$, which are both located in the north-western arm of the reservoir close to the shallow site s1. In contrast to this, no clear spatial pattern between sites was observed for $\mathrm{N}_{2} \mathrm{O}$ fluxes. Similarly, $\mathrm{N}_{2} \mathrm{O}$ fluxes measured amongst four sites, two shallow and two deep sites (s2, s4, d7 and d8), were not significantly 

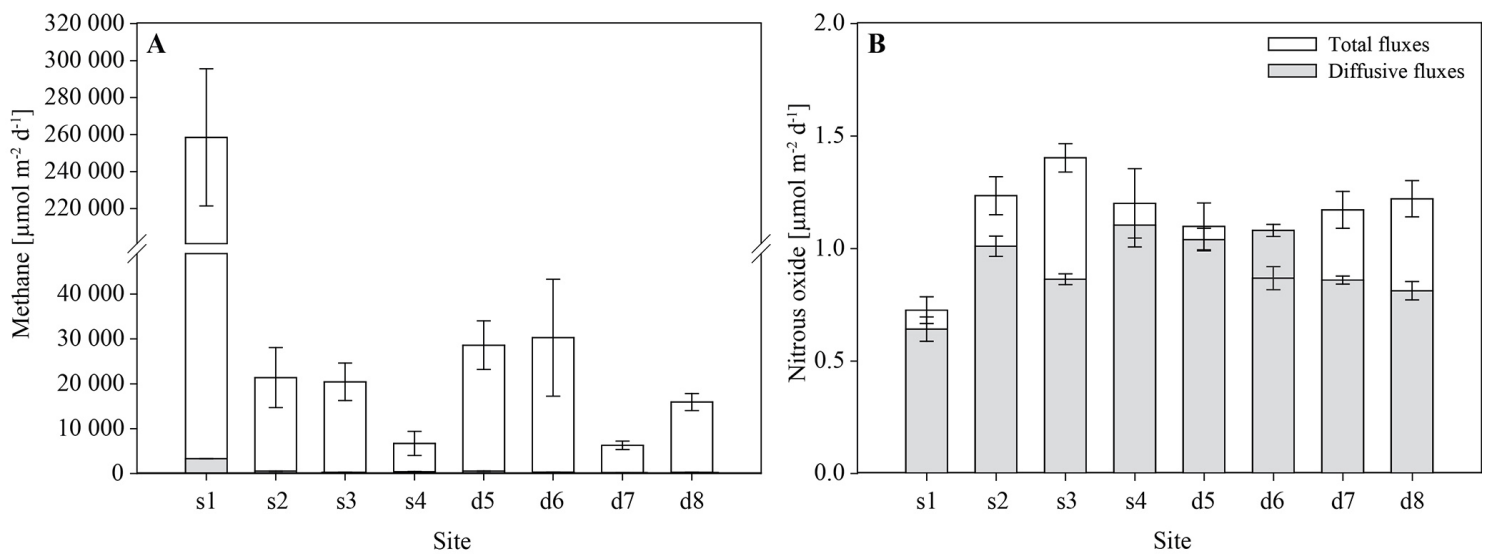

Figure 3. Total and diffusive methane (a) and nitrous oxide (b) fluxes at sampling sites s1-s4 and d5-d8. Total fluxes were determined using the anchored surface floating chambers, and diffusive fluxes were determined using the thin boundary layer model. Rates per site were averaged over three surface floating chamber deployments. Sampling sites are numbered from shallowest to deepest. Fluxes are given as average $\pm \mathrm{SE}, n=9$.

different $(P>0.05)$. However, $\mathrm{N}_{2} \mathrm{O}$ fluxes from sampling site $\mathrm{d} 6$ were different than all other sites $\left(\mathrm{KW}-\mathrm{H}_{7,72}=31.2\right.$, $P<0.01)$ apart from s1 and $\mathrm{d} 5(P>0.05)$. Interestingly, the lowest $\mathrm{N}_{2} \mathrm{O}$ fluxes were measured at the shallow site $\mathrm{s} 1$. Comparing total fluxes with diffusive fluxes from all sampling sites showed that in the spatial emission study, diffusive fluxes accounted for 1 to $6 \%$ of the total $\mathrm{CH}_{4}$ fluxes (Fig. 3a). Diffusive fluxes explain, in five out of the eight sites, 82 to $100 \%$ of total $\mathrm{N}_{2} \mathrm{O}$ fluxes; although, at one site, d6, the diffusive flux exceeded (by up to $25 \%$ ) the measured total flux (Fig. 3b; discussed in Sect. 4.1).

Wind speed during the spatial emission study (Supplement Fig. S2a) conducted at sites $\mathrm{s} 1-\mathrm{s} 4$ and d5-d8 increased from the first $\left(1.8 \pm 0.8 \mathrm{~m} \mathrm{~s}^{-1}\right)$ to the second $\left(2.8 \pm 1.4 \mathrm{~m} \mathrm{~s}^{-1}\right)$ chamber deployment as well as from the second to the third $\left(4.0 \pm 1.2 \mathrm{~m} \mathrm{~s}^{-1}\right)$ chamber deployment (deployment interval for each floating chamber was $1 \mathrm{~h}$ ). Averaged chamber $\mathrm{N}_{2} \mathrm{O}$ fluxes increased at all sites with increasing wind speed; however, the increase was not significant $(P>0.05)$ (Supplement Fig. S2b). In contrast to this, averaged $\mathrm{CH}_{4}$ fluxes at all sites did not increase with the increasing wind speed (Supplement Fig. S2c). Total chamber fluxes of each chamber deployment and per sampling site showed low variability for $\mathrm{N}_{2} \mathrm{O}$ and high variability for $\mathrm{CH}_{4}$.

Averaged total chamber $\mathrm{CH}_{4}$ fluxes were not significantly different $(P>0.05)$ between the two conducted studies (detailed study from March 2012 and spatial emission study from February 2014) for the shallow site s4. However, at the deep site $\mathrm{d} 7$, total $\mathrm{CH}_{4}$ fluxes differed significantly between the two studies $\left(\mathrm{KW}-\mathrm{H}_{1,39}=18.2, P<0.001\right)$. The total $\mathrm{N}_{2} \mathrm{O}$ fluxes at both sites, site $\mathrm{s} 4$ and site d7, differed significantly between the two studies $\left(\mathrm{KW}-\mathrm{H}_{1,39}=19.1, P<\right.$ 0.001 and $F_{1,37}=124.6, P<0.001$, respectively).

\subsection{Water column parameters}

Water column $\mathrm{CH}_{4}, \mathrm{~N}_{2} \mathrm{O}$ and nutrient concentrations at both sites $\mathrm{s} 4$ (Fig. 4a and b; Table 3) and d7 (Fig. 4c and d; Table 3$)$ showed no significant difference $(P>0.05)$ amongst the 5 consecutive experiment days and thus were pooled. The reservoir was characterised by a clear stratification with respect to oxygen (Supplement Fig. S3a). Epilimnetic layers were fully oxic, while metalimnetic layers were suboxic and the hypolimnetic layer at the deep site $\mathrm{d} 7$ was anoxic.

The epilimnion at both sites s4 and d7 was supersaturated with $\mathrm{CH}_{4}$ and $\mathrm{N}_{2} \mathrm{O} . \mathrm{CH}_{4}$ metalimnion concentrations at site $\mathrm{s} 4$ were 1 order of magnitude higher than the epilimnion concentrations. At site $\mathrm{d} 7$, hypolimnion $\mathrm{CH}_{4}$ concentrations were approximately $24000000 \%$ supersaturated and 2-3 orders of magnitude higher than the meta- and epilimnion concentrations, respectively. $\mathrm{N}_{2} \mathrm{O}$ concentrations were comparable for both sites $\mathrm{s} 4$ and $\mathrm{d} 7$ in the epilimnion and metalimnion. However, $\mathrm{N}_{2} \mathrm{O}$ concentrations at site $\mathrm{d} 7$ were highest in the epilimnion, not in the hypolimnion. The epilimnetic and metalimnetic $\mathrm{CH}_{4}$ and $\mathrm{N}_{2} \mathrm{O}$ concentrations at site $\mathrm{s} 4$ were comparable to the measured concentrations at site $\mathrm{d} 7$.

$\mathrm{NH}_{4}^{+}$concentrations at site s4 were not significantly different $(P>0.05)$ in epilimnion and metalimnion. $\mathrm{NO}_{2}^{-}$and $\mathrm{NO}_{3}^{-}$concentrations at site $\mathrm{s} 4$ showed slight increases between epilimnion and metalimnion. $\mathrm{NH}_{4}^{+}$concentrations at site $\mathrm{d} 7$ were similar in the epilimnion and metalimnion but 2 orders of magnitude higher in the hypolimnion. $\mathrm{NO}_{2}^{-}$and $\mathrm{NO}_{3}^{-}$concentrations at site $\mathrm{d} 7$ were not significantly different $(P>0.05)$ within each of the three investigated water column layers. All analysed $\mathrm{NH}_{4}^{+}, \mathrm{NO}_{2}^{-}$and $\mathrm{NO}_{3}^{-}$concentrations in epilimnion as well as metalimnion were comparable between site $\mathrm{s} 4$ and site $\mathrm{d} 7$. 

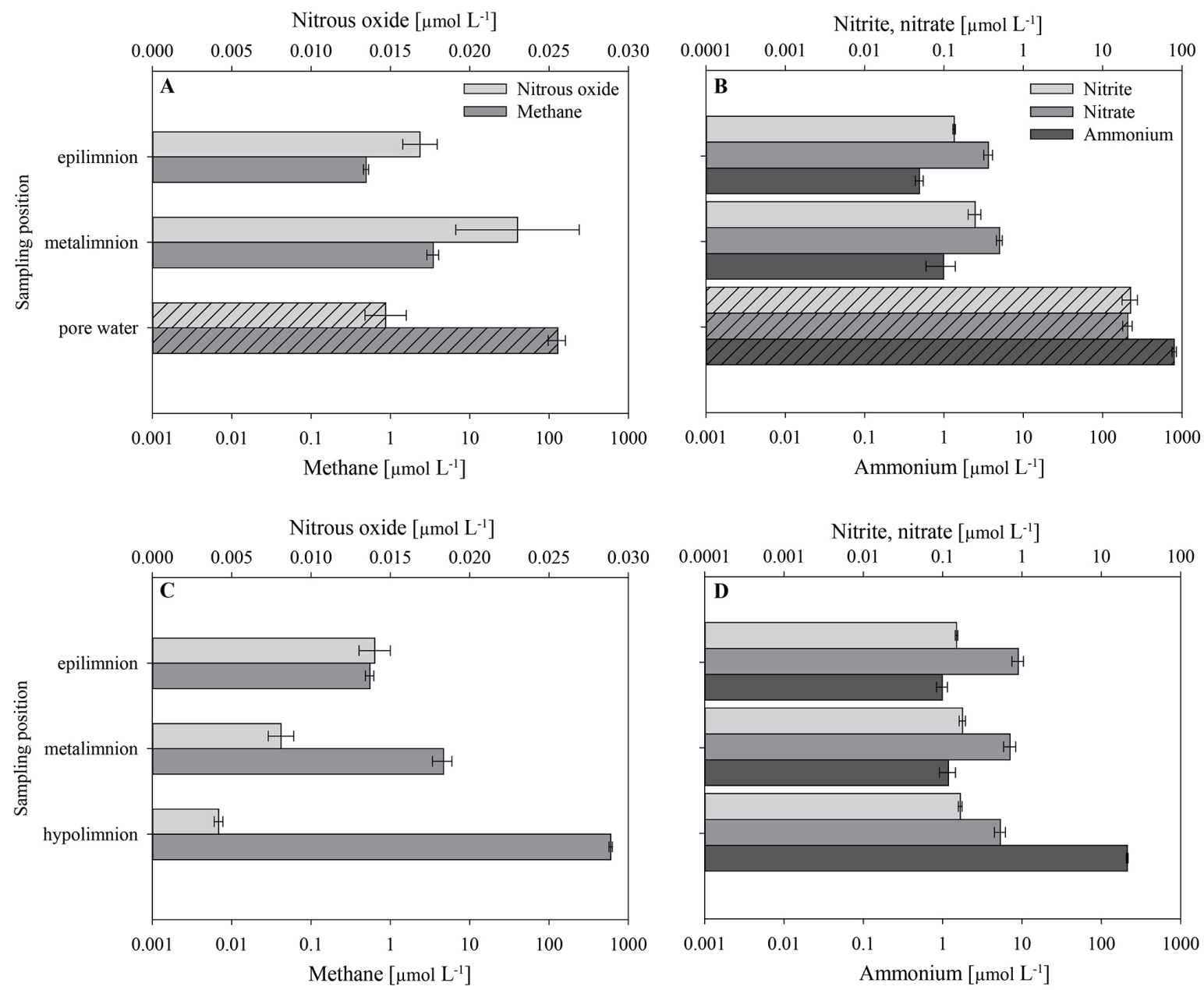

Figure 4. Levels of methane, nitrous oxide and nutrients determined at the shallow sampling site s4 (a, b) and at the deep sampling site d7 (c, d). Results are shown for the epilimnion, metalimnion and for pore water (bars with hatch pattern) at the shallow site s4 and for the epilimnion, metalimnion and hypolimnion at the deep site d7. Methane and nutrient concentrations are plotted on a log scale. Values represent averages \pm SE with the number of replicates being $n=12$ for water column methane and nitrous oxide, $n=15$ for nutrient water column samples, $n=4$ for pore water methane and nitrous oxide and $n=8$ for pore water nutrients.

\subsection{Pore water parameters}

The dissolved $\mathrm{CH}_{4}$ pore water concentrations at site s4 (Fig. 4a; Table 3) were 2 orders of magnitude higher than the concentrations measured in the epilimnion as well as in the metalimnion. The pore waters were approximately $5000000 \%$ supersaturated with $\mathrm{CH}_{4}$ (pore waters were collected from the upper sediment layers and the saturation percent was calculated as done for the water samples). $\mathrm{N}_{2} \mathrm{O}$ pore water concentrations at site $\mathrm{s} 4$ were comparable to measured concentrations in both investigated water column layers (epilimnion and metalimnion). $\mathrm{NH}_{4}^{+}$pore water concentrations at site s4 (Fig. 4b; Table 3) were 3 orders of magnitude higher than in the epilimnion and metalimnion. Similarly, the pore water $\mathrm{NO}_{2}^{-}$and $\mathrm{NO}_{3}^{-}$concentrations were 2 orders of magnitude higher than in the water column.

\subsection{Sediment-water fluxes}

$\mathrm{CH}_{4}$ was consistently produced during the incubations of the site $\mathrm{s} 4$ sediments (Fig. 5a, Table 4). $\mathrm{N}_{2} \mathrm{O}$ concentrations indicated consumption had occurred; however, these levels were low and near the theoretical detection limit from $72 \mathrm{~h}$ onwards (Fig. 5a). Dissolved oxygen was rapidly removed (Table 4) from overlying waters and was not detected after $48 \mathrm{~h}$ (Fig. 5a). $\mathrm{NH}_{4}^{+}$concentrations increased significantly $\left(F_{3,8}=6.1, P<0.01\right)$ between the start and end $(288 \mathrm{~h})$ of the incubation study. $\mathrm{NO}_{2}^{-}$concentrations were seen to have increased over time following the same pattern as $\mathrm{NH}_{4}^{+}$, while the $\mathrm{NO}_{3}^{-}$levels decreased (Fig. 5b; Table 4). 
Table 3. Measured methane, nitrous oxide and nutrient concentrations of the detailed study at the shallow site s4 in the epilimnion, metalimnion and pore water and at the deep site $\mathrm{d} 7$ in the epilimnion, metalimnion and hypolimnion. Values represent the average \pm SE: $n=12$ for water column methane and nitrous oxide; $n=15$ for water column nutrients; $n=4$ for pore water methane and nitrous oxide and $n=8$ for pore water nutrients.

\begin{tabular}{|c|c|c|c|c|}
\hline Site & $\begin{array}{l}\text { Measured } \\
\text { parameter }\end{array}$ & $\begin{array}{l}\text { Epilimnion } \\
\text { concentration }\end{array}$ & $\begin{array}{l}\text { Metalimnion } \\
\text { concentration }\end{array}$ & $\begin{array}{l}\text { Pore water } \\
\text { concentration }\end{array}$ \\
\hline \multirow[t]{5}{*}{ s4 } & $\mathrm{CH}_{4}$ & $\begin{array}{l}0.50 \pm 0.04 \mu \mathrm{mol} \mathrm{CH}_{4} \mathrm{~L}^{-1} \\
21986 \pm 2660 \% \text { saturation }\end{array}$ & $\begin{array}{l}3.47 \pm 0.60 \\
\mu \mathrm{mol} \mathrm{CH} \mathrm{CH}_{4}-1\end{array}$ & $\begin{array}{l}129 \pm 32 \\
\mu \mathrm{mol} \mathrm{CH} \mathrm{L}^{-1}\end{array}$ \\
\hline & $\mathrm{N}_{2} \mathrm{O}$ & $\begin{array}{l}0.017 \pm 0.001 \mu \mathrm{mol} \mathrm{N} \mathrm{OL} \mathrm{L}^{-1} \\
168 \pm 12 \% \text { saturation }\end{array}$ & $\begin{array}{l}0.023 \pm 0.004 \\
\mu \mathrm{mol} \mathrm{N} \mathrm{OL} \mathrm{L}^{-1}\end{array}$ & $\begin{array}{l}0.015 \pm 0.001 \\
\mu \mathrm{mol} \mathrm{N} 2 \mathrm{OL} \mathrm{L}^{-1}\end{array}$ \\
\hline & $\mathrm{NH}_{4}^{+}$ & 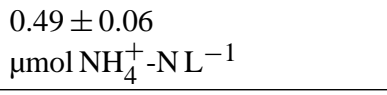 & 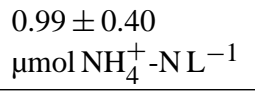 & 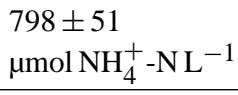 \\
\hline & $\mathrm{NO}_{2}^{-}$ & $\begin{array}{l}0.13 \pm 0.00 \\
\mu \mathrm{mol} \mathrm{NO}-\mathrm{NL}^{-1}\end{array}$ & $\begin{array}{l}0.25 \pm 0.04 \\
\mu \mathrm{mol} \mathrm{NO} \\
2-\mathrm{NL}^{-1}\end{array}$ & $\begin{array}{l}23 \pm 5 \\
\mu \mathrm{molNO}-\mathrm{NL}_{2}^{-1}\end{array}$ \\
\hline & $\mathrm{NO}_{3}^{-}$ & $\begin{array}{l}0.36 \pm 0.05 \\
\mu \mathrm{mol} \mathrm{NO}--\mathrm{NL}^{-1}\end{array}$ & $\begin{array}{l}0.50 \pm 0.04 \\
\mu \mathrm{mol} \mathrm{NO}-\mathrm{NL}^{-1}\end{array}$ & $\begin{array}{l}21 \pm 3 \\
\mu \mathrm{molNO}_{3}^{-}-\mathrm{NL}^{-1}\end{array}$ \\
\hline Site & $\begin{array}{l}\text { Measured } \\
\text { parameter }\end{array}$ & $\begin{array}{l}\text { Epilimnion } \\
\text { concentration }\end{array}$ & $\begin{array}{l}\text { Metalimnion } \\
\text { concentration }\end{array}$ & $\begin{array}{l}\text { Hypolimnion } \\
\text { concentration }\end{array}$ \\
\hline \multirow[t]{5}{*}{ d7 } & $\mathrm{CH}_{4}$ & $\begin{array}{l}0.55 \pm 0.07 \mu \mathrm{mol} \mathrm{CH}_{4} \mathrm{~L}^{-1} \\
19722 \pm 1465 \% \text { saturation }\end{array}$ & $\begin{array}{l}4.69 \pm 1.29 \\
\mu \mathrm{mol} \mathrm{CH} \mathrm{L}^{-1}\end{array}$ & $\begin{array}{l}600 \pm 28 \\
\mu \mathrm{mol} \mathrm{CH} \mathrm{L}^{-1}\end{array}$ \\
\hline & $\mathrm{N}_{2} \mathrm{O}$ & $\begin{array}{l}0.014 \pm 0.001 \mu \mathrm{mol} \mathrm{N} \mathrm{N}_{2} \mathrm{OL}^{-1} \\
206 \pm 14 \% \text { saturation }\end{array}$ & $\begin{array}{l}0.008 \pm 0.001 \\
\mu \mathrm{mol} \mathrm{N} \mathrm{OL} \mathrm{L}^{-1}\end{array}$ & $\begin{array}{l}0.004 \pm 0.000 \\
\mu \mathrm{mol} \mathrm{N} 2 \mathrm{OL}^{-1}\end{array}$ \\
\hline & $\mathrm{NH}_{4}^{+}$ & 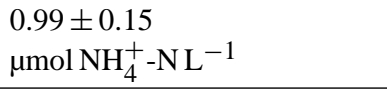 & 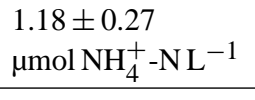 & 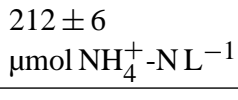 \\
\hline & $\mathrm{NO}_{2}^{-}$ & $\begin{array}{l}0.15 \pm 0.01 \\
\mu \mathrm{mol} \mathrm{NO} \\
2-\mathrm{NL}^{-1}\end{array}$ & 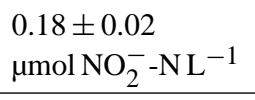 & 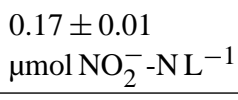 \\
\hline & $\mathrm{NO}_{3}^{-}$ & $\begin{array}{l}0.90 \pm 0.15 \\
\mu \mathrm{mol} \mathrm{NO}-\mathrm{NL}^{-1}\end{array}$ & $\begin{array}{l}0.71 \pm 0.12 \\
\mu \mathrm{mol} \mathrm{NO} \\
\end{array}$ & $\begin{array}{l}0.53 \pm 0.08 \\
\mu \mathrm{mol} \mathrm{NO}_{3}^{-}-\mathrm{NL}^{-1}\end{array}$ \\
\hline
\end{tabular}

Table 4. Production and consumption rates of methane, nitrous oxide and nutrients during the sediment incubation study. Positive values indicate production and negative values indicate consumption. Rates are given as an average $\pm \mathrm{SE}, n=3$.

\begin{tabular}{ll}
\hline $\begin{array}{l}\text { Measured } \\
\text { parameter }\end{array}$ & $\begin{array}{l}\text { Production/ } \\
\text { consumption rates }\end{array}$ \\
\hline $\mathrm{CH}_{4}$ & $3616 \pm 395 \mu \mathrm{mol} \mathrm{CH} \mathrm{m}^{-2}$ day $^{-1}$ \\
$\mathrm{DO}$ & $-38220 \mu \mathrm{mol} \mathrm{O} \mathrm{m}^{-2} \mathrm{day}^{-1}$ \\
$\mathrm{NH}_{4}^{+}$ & $3874 \pm 1129 \mu \mathrm{mol} \mathrm{NH}_{4}^{+}-\mathrm{N} \mathrm{m}^{-2} \mathrm{day}^{-1}$ \\
$\mathrm{NO}_{2}^{-}$ & $17 \pm 10 \mu \mathrm{mol} \mathrm{NO}_{2}^{-}-\mathrm{N} \mathrm{m}^{-2} \mathrm{day}^{-1}$ \\
$\mathrm{NO}_{3}^{-}$ & $-8 \pm 5 \mu \mathrm{mol} \mathrm{NO}$ \\
- & $-\mathrm{N} \mathrm{m}^{-2}$ day $^{-1}$ \\
\hline
\end{tabular}

$\mathrm{CH}_{4}, \mathrm{NH}_{4}^{+}, \mathrm{NO}_{2}^{-}, \mathrm{NO}_{3}^{-}$production/consumption rates were determined between hour 0 and 288 of the incubation experiment. The DO rate was determined between hour 0 and 48 of the incubation experiment.

\section{Discussion}

\subsection{Surface gas emissions and the dominance of $\mathrm{CH}_{4}$ ebullition}

The water-air flux measurements of the detailed study as well as the spatial emission study showed that the Gold Creek Reservoir was a source of $\mathrm{CH}_{4}$ and $\mathrm{N}_{2} \mathrm{O}$. Overall $\mathrm{CH}_{4}$ emissions emitted from the water surface were at least 1-2 (detailed study) or 2-4 (spatial emission study) orders of magnitude higher relative to $\mathrm{N}_{2} \mathrm{O}$ in terms of $\mathrm{CO}_{2}$ equivalents, despite $\mathrm{N}_{2} \mathrm{O}$ being a more powerful GHG than $\mathrm{CH}_{4}$.

The spatial emission study showed high variability of total $\mathrm{CH}_{4}$ fluxes across and within (amongst chamber deployments) all sampling sites and low variability of total $\mathrm{N}_{2} \mathrm{O}$ fluxes, indicating that fluxes were driven by ebullition and diffusion, respectively. These results agree with previous emission findings at sites $\mathrm{s} 4$ and $\mathrm{d} 7$ of the detailed study. High spatial variability of $\mathrm{CH}_{4}$ fluxes driven by ebullition has 


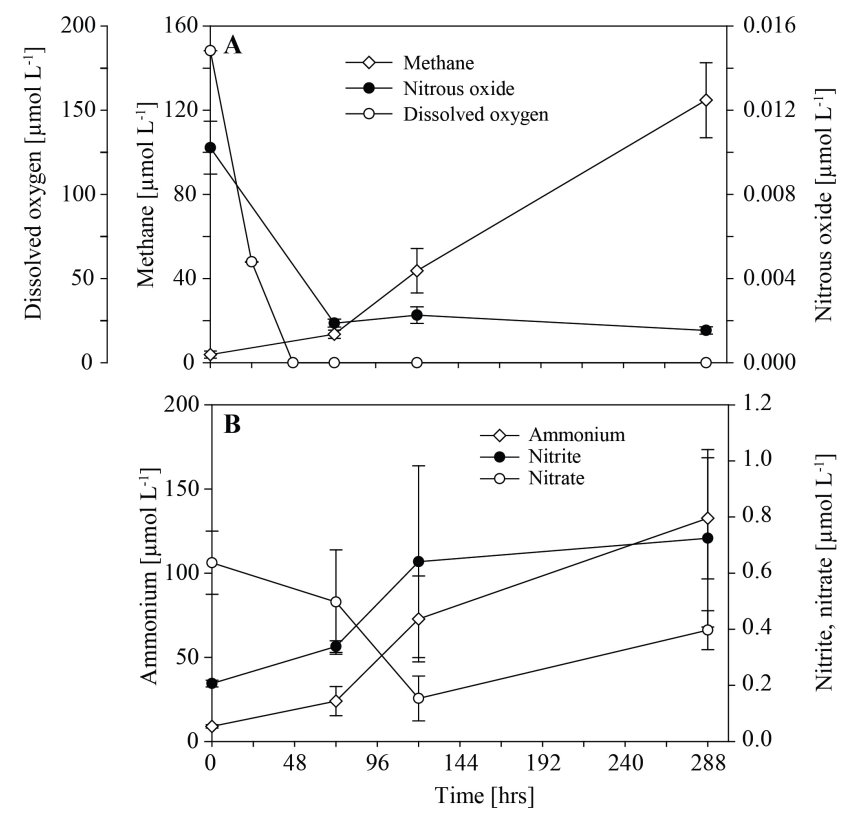

Figure 5. Sediment incubations of the shallow site s4: dissolved oxygen, methane, nitrous oxide (a) and nutrient production or consumption (b). Values represent averages $\pm \mathrm{SE}, n=3$.

been observed in other tropical reservoir studies (Bastviken et al., 2010; DelSontro et al., 2011; Grinham et al., 2011).

A comparison of the measured fluxes determined at the floating chambers and the estimated fluxes determined using the TBL model clearly showed that at all the sites the $\mathrm{CH}_{4}$ fluxes were mainly driven by ebullition and the $\mathrm{N}_{2} \mathrm{O}$ fluxes were mainly driven by diffusion. Our findings confirm those of previous studies, where ebullition has been shown to produce the largest $\mathrm{CH}_{4}$ emissions compared to the pathways of diffusion and plant-mediated transport. This is especially the case under the conditions of shallow and warm water systems where high $\mathrm{CH}_{4}$ production rates occur (DelSontro et al., 2011; Devol et al., 1988; Grinham et al., 2011; Joyce and Jewell, 2003; Keller and Stallard, 1994). Gold Creek Reservoir meets those conditions as it is a shallow system (maximum depth of $11.75 \mathrm{~m}$ ) experiencing warm temperatures (Supplement Fig. S3b) throughout the year. Diffusion is the dominant pathway for $\mathrm{N}_{2} \mathrm{O}$ emissions at Gold Creek Reservoir and this has been found in other tropical reservoirs (Guerin et al., 2008).

Estimated $\mathrm{N}_{2} \mathrm{O}$ fluxes in some cases exceeded the fluxes measured by the floating chambers. It is likely this anomaly results from inherent errors in both these methods. The estimates were based on one exemplary model for the gas transfer coefficient, $k$ (Wanninkhof, 1992). However, there are various models described that give over- or underestimations of measured fluxes and wide discrepancies in their results (Musenze et al., 2014; Ortiz-Llorente and Alvarez-Cobelas, 2012). In addition, modelled fluxes can be influenced by a number of factors that include rainfall on the water surface
(Guerin et al., 2007; Ho et al., 1997); spatial variations of wind speed (Matthews et al., 2003); heating and cooling of the water surface (Polsenaere et al., 2013; Rudorff et al., 2011); surrounding vegetation; and wind fetch (Cole et al., 2010). Emission rates in this study were modelled with averaged wind speeds for $k$ over the deployment time of $24 \mathrm{~h}$ periods (detailed study) and for $1 \mathrm{~h}$ periods (spatial emission study). Diurnal changes in wind speed occurred with higher wind speeds during daylight which was when the spatial study was conducted. Therefore, the deployment periods do not provide the same study conditions and could introduce an error; consequently, comparisons of daily rates between the two studies should be treated with caution.

\subsection{Factors controlling $\mathrm{CH}_{4}$ ebullition}

Both studies (detailed and spatial emission) showed that ebullition from anoxic sediments was the main contributor to the total $\mathrm{CH}_{4}$ emissions in this subtropical reservoir. The detailed study showed that ebullitive $\mathrm{CH}_{4}$ fluxes were higher at site $\mathrm{s} 4$ than at site $\mathrm{d} 7$. The spatial emission study revealed that ebullitive $\mathrm{CH}_{4}$ fluxes at site s1 were significantly higher than at all deep sites. These results confirm findings from Bastviken et al. (2004) showing that $\mathrm{CH}_{4}$ fluxes by ebullition are depth-dependent and higher at water depths of $4 \mathrm{~m}$ or less. Ebullition, and ultimately $\mathrm{CH}_{4}$ emission, can be enhanced when the hydrostatic pressure is reduced which could be a result of current-induced bottom shear stress or the lowering of storage water levels (Joyce and Jewell, 2003; Ostrovsky et al., 2008). The already quite low hydrostatic pressure in the Gold Creek Reservoir (i.e. <2 atmospheres) favours active ebullition there. The $\mathrm{CH}_{4}$ in the gas bubbles can escape oxidation during the transport through the water column as $\mathrm{CH}_{4}$ moves faster through the water column by ebullition than by diffusion (Joyce and Jewell, 2003). Interestingly, however, significantly higher ebullition rates were not found at the other shallow sites (s2-s4) as compared to the deeper sites. Highest $\mathrm{CH}_{4}$ water-air fluxes of the spatial emission study were generally found at the shallow site $\mathrm{s} 1$ and the deep sites $\mathrm{d} 5$ and $\mathrm{d} 6$, located in the north-western arm of the reservoir. These three sites (s1, d5 and d6) are located where the main water inflow to the reservoir would occur, and these likely receive high amounts of organic matter compared to the other sites. Hence, higher $\mathrm{CH}_{4}$ production resulting in higher fluxes would occur at these sites. This would also explain why $\mathrm{CH}_{4}$ fluxes at the shallow sites s2-s4 did not support other findings of depth-dependent fluxes as they likely receive less organic matter than received in the northwestern sidearm of the reservoir. The chlorophyll $a$ profile indicated that phytoplankton was predominantly present in the upper $2 \mathrm{~m}$ of the water column (Supplement Fig. S3c). Phytoplankton were also present in the deeper aphotic layers, suggesting these are a source of organic carbon to the sediments. However, the spatial pattern in ebullition indicates that the major source of organic carbon is generated from the 
surrounding catchment as the highest $\mathrm{CH}_{4}$ flux rates were found adjacent to major inflows where there was intense forest litter deposition. This phenomenon has been observed in other storages within the region (Grinham et al., 2011) and highlights the importance of identifying ebullition hot spots to improve total emission estimates.

The $\mathrm{CH}_{4}$ fluxes from Gold Creek Reservoir compare well with other reservoirs (Table 5) in the South East Queensland region (e.g. Little Nerang Dam (Grinham et al., 2011) and Baroon Pocket Dam (Grinham et al., 2012)) and even exceeded the rates of younger reservoirs (e.g. Lake Wivenhoe and Baroon Pocket Dam; Grinham et al., 2012). The age of a reservoir is described as one of the parameters affecting GHG fluxes as it is often described that fluxes tend to decline with the reservoir age (Abril et al., 2005; Galy-Lacaux et al., 1999). Barros et al. (2011) used published data from different hydroelectric reservoirs to show that the relationship between $\mathrm{CH}_{4}$ flux and reservoir age is negatively correlated. However, $\mathrm{CH}_{4}$ fluxes from reservoirs measured in South East Queensland (Table 5) significantly exceeded the fluxes analysed by Barros et al. (2011), and the older reservoirs in the region showed higher $\mathrm{CH}_{4}$ emissions rates than the younger reservoirs. This may be explained by intensive, irregular precipitation events that occur in the region, and these would periodically flush high amounts of organic matter into the system. It is likely that these bursts of high organic loadings would allow the ebullitive pathways for $\mathrm{CH}_{4}$ emissions to persist and maintain high fluxes over time.

\subsection{Sources of $\mathrm{CH}_{4}$ production}

Generally, the highest $\mathrm{CH}_{4}$ concentrations in the Gold Creek Reservoir were found in the hypolimnion and sediments, indicating the sediments as a main source of $\mathrm{CH}_{4}$. The hypolimnetic $\mathrm{CH}_{4}$ concentrations were comparable to concentrations found in other stratified, tropical reservoirs (Abril et al., 2005; Galy-Lacaux et al., 1999; Guerin and Abril, 2007). Epilimnetic $\mathrm{CH}_{4}$ concentrations were 3 orders of magnitude lower than concentrations in the hypolimnion, indicating that a substantial portion of the $\mathrm{CH}_{4}$ was oxidised by $\mathrm{CH}_{4}$ oxidising bacteria before reaching the surface waters and the atmosphere, as has been suggested to occur in other tropical reservoirs (Guerin and Abril, 2007; Lima, 2005). These epilimnion concentrations were comparable (Guerin and Abril, 2007) or significantly lower (up to 3 orders of magnitude) than concentrations found in other stratified, tropical reservoirs (Abril et al., 2005). Despite lower $\mathrm{CH}_{4}$ concentrations in the epilimnion, the reservoir was still supersaturated with $\mathrm{CH}_{4}$ and a source to the atmosphere.

The laboratory incubations showed that the sediments of Gold Creek Reservoir were a consistent source of $\mathrm{CH}_{4}$ as the $\mathrm{CH}_{4}$ concentration steadily increased throughout the incubation period. This supports the findings of the field study where $\mathrm{CH}_{4}$ sediment pore water concentrations were greatly elevated relative to the surface water concentrations. The
Table 5. The range of methane fluxes across selected reservoirs (covering shallow and deep sites) in South East Queensland.

\begin{tabular}{lcl}
\hline Reservoir & $\begin{array}{c}\text { Commission } \\
\text { year }\end{array}$ & $\begin{array}{l}\mathrm{CH}_{4} \text { flux ranges } \\
\left(\mu \mathrm{mol} \mathrm{CH} \mathrm{CH}_{4} \mathrm{day}^{-1}\right)\end{array}$ \\
\hline $\begin{array}{l}\text { Baroon Pocket Dam } \\
\text { (Grinham et al., 2012) }\end{array}$ & 1988 & $505-251750$ \\
$\begin{array}{l}\text { Lake Wivenhoe } \\
\text { (Grinham et al., 2012) }\end{array}$ & 1984 & $95-78500$ \\
$\begin{array}{l}\text { Little Nerang Dam } \\
\text { (Grinham et al., 2011) }\end{array}$ & 1962 & $4230-1403250$ \\
$\begin{array}{l}\text { Gold Creek Reservoir } \\
\text { (this study) }\end{array}$ & 1885 & $414-306302$ \\
\hline
\end{tabular}

high methanogenesis rates in the sediments are thus likely driving a significant portion of the water-air $\mathrm{CH}_{4}$ fluxes measured in this study. Past studies have demonstrated that sediments are a significant $\mathrm{CH}_{4}$ source (Barros et al., 2011; Canfield et al., 2005). A recent study on a similar reservoir system clearly demonstrated the dominance of methanogenic archaea in the upper $15 \mathrm{~cm}$ of the sediment zone (Green et al., 2012). Given the high rates of organic matter loading in these systems, $\mathrm{CH}_{4}$ production will be an important pathway for organic matter degradation in the sediments. The highly supersaturated concentrations of the pore waters of this relatively shallow reservoir means that any small changes in hydrostatic pressure, e.g. via bottom shear, would likely increase the ebullition rates (Joyce and Jewell, 2003). In comparison of the $\mathrm{CH}_{4}$ sediment-water fluxes with the $\mathrm{CH}_{4}$ water-air fluxes from the shallow site $\mathrm{s} 4$, it was evident that the sediment efflux $\left(3616 \pm 395 \mu \mathrm{mol} \mathrm{CH}_{4} \mathrm{~m}^{-2}\right.$ day $\left.^{-1}\right)$ explained $67 \%$ of the diffusive $\mathrm{CH}_{4}$ emissions $\left(5400 \pm 1250 \mu \mathrm{mol} \mathrm{CH}_{4} \mathrm{~m}^{-2} \mathrm{day}^{-1}\right)$ and $35 \%$ of the total $\mathrm{CH}_{4}$ emissions $\left(10423 \pm 1249 \mu \mathrm{mol} \mathrm{CH}_{4} \mathrm{~m}^{-2}\right.$ day $\left.^{-1}\right)$. This strongly indicates that the fluxes assessed during the sediment incubations in this study were underestimated. The most influential factor for this underestimation is likely the height of the incubated sediment core. With a height of only about $10 \mathrm{~cm}$, the $\mathrm{CH}_{4}$ production from deeper (also anoxic) sediment layers was not considered.

\subsection{Sources of $\mathrm{N}_{2} \mathrm{O}$ production or consumption}

The sediment incubation study clearly showed that the anoxic sediments were the source of $\mathrm{NH}_{4}^{+}$for the $\mathrm{N}_{2} \mathrm{O}$ production (Fig. 5b). However, $\mathrm{N}_{2} \mathrm{O}$ production through either the nitrification or denitrification pathway ultimately requires DO. Dissolved oxygen is introduced into the upper water layer through wind re-aeration or by photosynthetic production. The production of $\mathrm{N}_{2} \mathrm{O}$, therefore, suffers from twin limitations; below the oxycline DO is limiting, whereas above the oxycline, $\mathrm{NH}_{4}^{+}$is limiting. This confines $\mathrm{N}_{2} \mathrm{O}$ production to a narrow band within the water column in deep sites or to upper sediment layers in shallow sites and limits 
the degree of supersaturation and, therefore, the likelihood of bubble production. The net result was that $\mathrm{N}_{2} \mathrm{O}$ emissions from the water surface predominately occurred through the diffusive pathway.

Our measurements showed that the surface waters were supersaturated with $\mathrm{N}_{2} \mathrm{O}$ so the system was acting as a $\mathrm{N}_{2} \mathrm{O}$ source to the atmosphere. The elevated $\mathrm{N}_{2} \mathrm{O}$ concentrations in the oxic zones (epilimnion and metalimnion) relative to the anoxic zones indicate that nitrification was the predominant production pathway. $\mathrm{N}_{2} \mathrm{O}$ consumption occurs in the anoxic hypolimnion and sediments possibly via denitrification as found previously (Guerin et al., 2008; Mengis et al., 1997). The presence of $\mathrm{NO}_{3}^{-}$within the anoxic zones further supports the likelihood of denitrification.

\subsection{Implications}

Intensive field and laboratory studies in Gold Creek Reservoir were undertaken to improve the understanding of production/consumption and emission rates of the non- $\mathrm{CO}_{2}$ GHGs, $\mathrm{CH}_{4}$ and $\mathrm{N}_{2} \mathrm{O}$. Our results clearly demonstrate that the Gold Creek Reservoir is a source of $\mathrm{CH}_{4}$ and $\mathrm{N}_{2} \mathrm{O}$ to the atmosphere although $\mathrm{CH}_{4}$ is clearly the dominant gas even when expressed as $\mathrm{CO}_{2}$ equivalents. $\mathrm{N}_{2} \mathrm{O}$ flux rates were in fact much lower than those reported in other reservoirs with similar climates $\left(\mathrm{N}_{2} \mathrm{O}\right.$ fluxes from six reservoirs of three countries (Brazil, Panama, French Guiana) ranged between 3-157 $\mu \mathrm{mol} \mathrm{N}_{2} \mathrm{O} \mathrm{m}^{-2}$ day $^{-1}$ (Guerin et al., 2008); in comparison, the fluxes in this study range between 0.73-2.89 $\mu \mathrm{mol} \mathrm{N}_{2} \mathrm{O} \mathrm{m}^{-2}$ day $^{-1}$ ). Gold Creek Reservoir $\mathrm{CH}_{4}$ fluxes, on the other hand $\left(53 \mathrm{tCH}_{4} \mathrm{yr}^{-1}\right.$; range between 7-290 $\mathrm{tCH}_{4} \mathrm{yr}^{-1}$ ), were dominated by ebullitive emissions and were within the range reported for other tropical systems (St. Louis et al., 2000). The exception was the flux measured at the shallowest site (s1) which greatly exceeded even the higher-end range from the young (filled in 1994) Petit Saut Dam in French Guiana (Galy-Lacaux et al., 1997; St. Louis et al., 2000). Barros et al. (2011) determined that the relationship between $\mathrm{CH}_{4}$ flux and latitude is significantly negatively correlated. $\mathrm{CH}_{4}$ fluxes from Gold Creek Reservoir (spatial emission study range between $6300-258535 \mu \mathrm{mol} \mathrm{CH}_{4} \mathrm{~m}^{-2} \mathrm{day}^{-1}$ ), situated at the latitude of $27^{\circ} 45^{\prime} 97^{\prime \prime} \mathrm{S}$, significantly exceeded the fluxes presented in that study, which were given to be in general less than $4167 \mu \mathrm{mol} \mathrm{CH}_{4} \mathrm{~m}^{-2} \mathrm{day}^{-1}$. The catchment of the Gold Creek Reservoir consists of $98 \%$ forest and experiences warm temperatures as well as intense precipitation events that potentially flush high amounts of organic matter into the reservoir throughout the year. These characteristics are in contrast to temperate systems and likely accelerate the $\mathrm{CH}_{4}$ production in subtropical systems like the Gold Creek Reservoir. The high rates of $\mathrm{CH}_{4}$ flux that we measured further highlight the importance of studies that focus on subtropical systems. Additionally, studies from tropical freshwater systems are also important as these experience higher water temperatures than subtropical systems and are thus expected to exhibit even higher surface $\mathrm{CH}_{4}$ fluxes (Barros et al., 2011). There is a lack of study of Australia's reservoirs in both the tropical and subtropical climate zones, and their contribution as significant $\mathrm{CH}_{4}$ emitters is not recognised. Future emission studies of these systems would add to the limited knowledge of this region, which is important for inclusion in global GHG estimates.

The spatial variability results of our study further emphasise the importance of including a reasonable spatial resolution when monitoring GHG emissions from water bodies, particularly when measuring $\mathrm{CH}_{4}$. In addition, monitoring efforts should include measuring $\mathrm{CH}_{4}$ ebullition as it is the most dominant pathway in these systems. For $\mathrm{N}_{2} \mathrm{O}$, however, assessing only diffusive fluxes is likely sufficient. Our results also suggest that reservoir age is potentially not an important parameter affecting $\mathrm{CH}_{4}$ fluxes in systems similar to Gold Creek Reservoir. Ultimately, the results presented here are likely to be globally relevant as an increasing number of large reservoirs are being constructed to meet growing water demand, particularly in tropical and subtropical zones, but also because subtropical systems can provide insight into the possible impacts that a warming climate will have on temperate reservoirs.

\section{The Supplement related to this article is available online at doi:10.5194/bg-11-5245-2014-supplement.}

Acknowledgements. The authors gratefully acknowledge the support and collaboration of Michele Burford at Griffith University. The advice and assistance provided by the RS\&T team, Andrew Watkinson and Duncan Middleton of Seqwater are also gratefully acknowledged. We would like to thank Tonya DelSontro for the very helpful guidance provided during the manuscript reviewing process. We thank the three anonymous reviewers whose suggestions have greatly improved this manuscript. We also would like to thank Philip Bond for a thorough review of the manuscript. This project was financially supported by the Australian Research Council (ARC) project LP100100325.

Edited by: T. DelSontro

\section{References}

Abril, G., Guerin, F., Richard, S., Delmas, R., Galy-Lacaux, C., Gosse, P., Tremblay, A., Varfalvy, L., Dos Santos, M. A., and Matvienko, B.: Carbon dioxide and methane emissions and the carbon budget of a 10-year old tropical reservoir (Petit Saut, French Guiana), Global Biogeochem. Cy., 19, GB4007, doi:10.1029/2005gb002457, 2005.

Barros, N., Cole, J. J., Tranvik, L. J., Prairie, Y. T., Bastviken, D., Huszar, V. L. M., del Giorgio, P., and Roland, F.: Carbon emission from hydroelectric reservoirs linked to reservoir age and latitude, Nat. Geosci., 4, 593-596, doi:10.1038/ngeo1211, 2011. 
Bastien, J. and Demarty, M.: Spatio-temporal variation of gross $\mathrm{CO}_{2}$ and $\mathrm{CH}_{4}$ diffusive emissions from Australian reservoirs and natural aquatic ecosystems, and estimation of net reservoir emissions, Lakes \& Reservoirs Research and Management, 18, 115127, doi:10.1111/lre.12028, 2013.

Bastviken, D., Cole, J., Pace, M., and Tranvik, L.: Methane emissions from lakes: Dependence of lake characteristics, two regional assessments, and a global estimate, Global Biogeochem. Cy., 18, GB4009, doi:10.1029/2004gb002238, 2004.

Bastviken, D., Santoro, A. L., Marotta, H., Pinho, L. Q., Calheiros, D. F., Crill, P., and Enrich-Prast, A.: Methane emissions from Pantanal, South America, during the low water season: Toward more comprehensive sampling, Environ. Sci. Technol., 44, 54505455, doi:10.1021/es1005048, 2010.

Bastviken, D., Tranvik, L. J., Downing, J. A., Crill, P. M., and Enrich-Prast, A.: Freshwater methane emissions offset the continental carbon sink, Science, 331, 6013, doi:10.1126/science.1196808, 2011.

Canfield, D. E., Erik, K., and Bo, T.: The Methane Cycle, in: Advances in Marine Biology, edited by: Donald, E., Canfield, E. K., and Bo, T., Academic Press, 383-418, 2005.

Climate Data Online, Bureau of Meteorology, Copyright Commonwealth of Australia, available at: www.bom.gov.au, last access: 6 October, 2013.

Cole, J. J., Bade, D. L., Bastviken, D., Pace, M. L., and Van de Bogert, M.: Multiple approaches to estimating air-water gas exchange in small lakes, Limnol. Oceanogr.-Methods, 8, 285-293, doi:10.4319/lom.2010.8.285, 2010.

Crusius, J. and Wanninkhof, R.: Gas transfer velocities measured at low wind speed over a lake, Limnol. Oceanogr., 48, 1010-1017, 2003.

DelSontro, T., Kunz, M. J., Kempter, T., Wuest, A., Wehrli, B., and Senn, D. B.: Spatial heterogeneity of methane ebullition in a large tropical reservoir, Environ. Sci. Technol., 45, 9866-9873, doi:10.1021/es2005545, 2011.

Demarty, M. and Bastien, J.: GHG emissions from hydroelectric reservoirs in tropical and equatorial regions: Review of 20 years of $\mathrm{CH}_{4}$ emission measurements, Energ. Policy, 39, 4197-4206, doi:10.1016/j.enpol.2011.04.033, 2011.

Devol, A. H., Richey, J. E., Clark, W. A., King, S. L., and Martinelli, L. A.: Methane emissions to the troposphere from the Amazon Floodplain, J. Geophys. Res.-Atmos., 93, 1583-1592, doi:10.1029/JD093iD02p01583, 1988.

Fearnside, P. M.: Hydroelectric dams in the Brazilian Amazon as sources of greenhouse gases, Environ. Conserv., 22, 7-19, 1995.

Galy-Lacaux, C., Delmas, R., Jambert, C., Dumestre, J.-F., Labroue, L., Richard, S., and Gosse, P.: Gaseous emissions and oxygen consumption in hydroelectric dams: A case study in French Guyana, Global Biogeochemical Cy., 11, 471-483, doi:10.1029/97gb01625, 1997.

Galy-Lacaux, C., Delmas, R., Kouadio, G., Richard, S., and Gosse, P.: Long-term greenhouse gas emissions from hydroelectric reservoirs in tropical forest regions, Global Biogeochem. Cy., 13, 503-517, doi:10.1029/1998gb900015, 1999.

Geoscience Australia: Dams and water storages 1990, available at: www.ga.gov.au, 2004.

Green, T. J., Barnes, A. C., Bartkow, M., Gale, D., and Grinham, A.: Sediment bacteria and archaea community analysis and nutrient fluxes in a sub-tropical polymictic reservoir, Aquat. Microbial Ecol., 65, 287-302, 2012.

Grinham, A., Dunbabin, M., Gale, D., and Udy, J.: Quantification of ebullitive and diffusive methane release to atmosphere from a water storage, Atmos. Environ., 45, 7166-7173, doi:10.1016/j.atmosenv.2011.09.011, 2011.

Grinham, A., Gibbes, B., Cutts, N., Kvennefors, C., Jinks, D., and Dunbabin, M.: Quantifying natural GHG sources and sinks: Lake Wivenhoe and Baroon Pocket Dam, Seqwater internal report, The University of Queensland, 2012.

Guerin, F. and Abril, G.: Significance of pelagic aerobic methane oxidation in the methane and carbon budget of a tropical reservoir, J. Geophys. Res.-Biogeo., 112, G03006, doi:10.1029/2006jg000393, 2007.

Guerin, F., Abril, G., Serca, D., Delon, C., Richard, S., Delmas, R., Tremblay, A., and Varfalvy, L.: Gas transfer velocities of $\mathrm{CO}_{2}$ and $\mathrm{CH}_{4}$ in a tropical reservoir and its river downstream, J. Mar. Syst., 66, 161-172, doi:10.1016/j.jmarsys.2006.03.019, 2007.

Guerin, F., Abril, G., Tremblay, A., and Delmas, R.: Nitrous oxide emissions from tropical hydroelectric reservoirs, Geophys. Res. Lett., 35, L06404, doi:10.1029/2007g1033057, 2008.

Ho, D. T., Bliven, L. F., Wanninkhof, R., and Schlosser, P.: The effect of rain on air-water gas exchange, Tellus B, 49, 149-158, doi:10.1034/j.1600-0889.49.issue2.3.x, 1997.

IPCC: Climate Change 2007 - The Physical Science Basis, Cambridge University Press, Cambridge, United Kingdom and New York, NY, USA, 2007.

Joyce, J. and Jewell, P. W.: Physical controls on methane ebullition from reservoirs and lakes, Environ. Eng. Geosci., 9, 167-178, doi:10.2113/9.2.167, 2003.

Keller, M. and Stallard, R. F.: Methane emissions by bubbling from Gatun Lake, Panama, J. Geophys. Res.-Atmos., 99, 8307-8319, doi:10.1029/92jd02170, 1994.

Lima, I. B. T.: Biogeochemical distinction of methane releases from two Amazon hydroreservoirs, Chemosphere, 59, 1697 1702, doi:10.1016/j.chemosphere.2004.12.011, 2005.

Lipschultz, F., Wofsy, S. C., Ward, B. B., Codispoti, L. A., Friedrich, G., and Elkins, J. W.: Bacterial transformations of inorganic nitrogen in the oxygen-deficient waters of the Eastern Tropical South Pacific Ocean, Deep-Sea Res., 37, 1513-1541, doi:10.1016/0198-0149(90)90060-9, 1990.

Matthews, C. J. D., St. Louis, V. L., and Hesslein, R. H.: Comparison of three techniques used to measure diffusive gas exchange from sheltered aquatic surfaces, Environ. Sci. Technol., 37, 772790, 2003.

Mendonça, R., Barros, N., Vidal, L. O., Pacheco, F., Kosten, S., and Roland, F.: Greenhouse gas emissions from hydroelectric reservoirs: what knowledge do we have and what is lacking?, in: Greenhouse Gases - Emission, Measurement and Management, edited by: Liu, D. G., 55-78, 2012.

Mengis, M., Gachter, R., and Wehrli, B.: Sources and sinks of nitrous oxide $\left(\mathrm{N}_{2} \mathrm{O}\right)$ in deep lakes, Biogeochemistry, 38, 281-301, doi:10.1023/a:1005814020322, 1997.

Musenze, R. S., Werner, U., Grinham, A., Udy, J., and Yuan, Z.: Methane and nitrous oxide emissions from a subtropical estuary (the Brisbane River estuary, Australia), Sci. Total Environ., 472, 719-729, 2014.

Ortiz-Llorente, M. J. and Alvarez-Cobelas, M.: Comparison of biogenic methane emissions from unmanaged estuaries, lakes, 
oceans, rivers and wetlands, Atmos. Environ., 59, 328-337, doi:10.1016/j.atmosenv.2012.05.031, 2012.

Ostrovsky, I., McGinnis, D. F., Lapidus, L., and Eckert, W.: Quantifying gas ebullition with echosounder: the role of methane transport by bubbles in a medium-sized lake, Limnol. Oceanogr.Methods, 6, 105-118, 2008.

Polsenaere, P., Deborde, J., Detandt, G., Vidal, L. O., Perez, M. A. P., Marieu, V., and Abril, G.: Thermal enhancement of gas transfer velocity of $\mathrm{CO}_{2}$ in an Amazon floodplain lake revealed by eddy covariance measurements, Geophys. Res. Lett., 40, 17341740, doi:10.1002/grl.50291, 2013.

Queensland Department of Science Information Technology Innovation and the Arts: Land cover change in Queensland 2009-10: a Statewide Landcover and Trees Study (SLATS) report, DSITIA, Brisbane, 2012.

Ramos, F. M., Lima, I. B. T., Rosa, R. R., Mazzi, E. A., Carvalho, J. C., Rasera, M., Ometto, J., Assireu, A. T., and Stech, J. L.: Extreme event dynamics in methane ebullition fluxes from tropical reservoirs, Geophys. Res. Lett., 33, L21404, doi:10.1029/2006g1027943, 2006.

Rudorff, C. M., Melack, J. M., MacIntyre, S., Barbosa, C. C. F., and Novo, E.: Seasonal and spatial variability of $\mathrm{CO}_{2}$ emission from a large floodplain lake in the lower Amazon, J. Geophys. Res.-Biogeo., 116, G04007, doi:10.1029/2011jg001699, 2011.

Seitzinger, S. P. and Kroeze, C.: Global distribution of nitrous oxide production and $\mathrm{N}$ inputs in freshwater and coastal marine ecosystems, Global Biogeochem. Cy., 12, 93-113, doi:10.1029/97gb03657, 1998.

Soumis, N., Lucotte, M., Canuel, R., Weissenberger, S., Houel, S., Larose, C., and Duchemin, É.: Hydroelectric reservoirs as anthropogenic sources of greenhouse gases, in: Water Encyclopedia, John Wiley \& Sons, Inc., 2005.
St. Louis, V. L., Kelly, C. A., Duchemin, É., Rudd, J. W. M., and Rosenberg, D. M.: Reservoir surfaces as sources of greenhouse gases to the atmosphere: A global estimate, BioScience, 50, 766775, doi:10.1641/0006-3568(2000)050[0766:rsasog]2.0.co;2, 2000.

Tremblay, A., Varfalvy, L., Roehm, C., and Garneau, M.: Greenhouse gas emissions - fluxes and processes. Hydroelectric reservoirs and natural environments, 1st Edn., Springer, Berlin, 2005.

Tundisi, J. G. and Tundisi, T. M.: Limnology, CRC Press/Balkema, Leiden, The Netherlands, 2012.

Tundisi, J. G., Matsumura-Tundisi, T., and Calijuri, M. C.: Limnology and management of reservoirs in Brazil, in: Comparative Reservoir Limnology and Water Quality Management, edited by: Straškraba, M., Tundisi, J. G., and Duncan, A., Developments in Hydrobiology, Springer Netherlands, 25-55, 1993.

Wanninkhof, R.: Relationship between wind speed and gas exchange over the ocean, J. Geophys. Res.-Oceans, 97, 7373-7382, doi:10.1029/92jc00188, 1992.

Ward, B. B.: Nitrification and denitrification: Probing the nitrogen cycle in aquatic environments, Microbial Ecol., 32, 247-261, 1996.

Weiss, R. F. and Price, B. A.: Nitrous oxide solubility in water and seawater, Mar. Chem., 8, 347-359, doi:10.1016/03044203(80)90024-9, 1980.

Yamamoto, S., Alcauskas, J. B., and Crozier, T. E.: Solubility of methane in distilled water and seawater, J. Chem. Eng. Data, 21, 78-80, doi:10.1021/je60068a029, 1976.

Zar, J. H.: Biostatistical analysis, Biostatistical analysis, PrenticeHall Inc., New Jersey, i-xiv, 1-718 pp., 1984. 